\title{
17 Pope Francis on Europe
}

\author{
Ewa Kozerska
}

\section{Introduction}

Centuries-old events, entwined with dynamic civilisational transformations on the continent of Europe, continue to be a relevant subject of numerous analyses and comments among opinion-forming circles, primarily intellectuals, journalists and representatives of public authorities. Therefore, it is only natural that this subject arouses keen interest in the Roman Catholic Church, and first and foremost in the papacy. The activity of the Bishop of Rome in this area is justified by his political sovereignty over the papal state, which has existed historically in an area of Europe. It is also undoubtedly conditioned by his spiritual and institutional guidance over Christianity, which dominates this part of the world. Pontiffs select as subjects of special reflection the events and processes that, in their opinion, have potentially major, perhaps even ground-breaking, significance for this continent. Due to the essence of their function, pastoral teachings are primarily dominated by axiological issues, but they also refer to closely related pragmatic aspects of politics, economics and ecology. Importantly, rapid geopolitical and technological changes (especially after the Second World War), which favoured a clear polarisation of the world, weakened the leading role of the Old Continent in the international order. Therefore, the multiple and inevitable global changes meant that the successors of the original pope, Peter, especially in recent decades, have begun to perceive Eurocentrism from a broader and slightly different perspective. In the tradition of the Church to date, this worldview essentially results from Western civilisation, which grew and put down roots in this part of the world and which has quite permanently penetrated certain parts of other continents (especially Latin America, from where the current pope hails). ${ }^{1}$ To a certain extent, it is also a consequence of the legitimate belief in the pioneering role of Europe in many areas, its dominance as a centre of governance and its importance as one of the main players and decision-makers on an international scale. Since the middle of the 20th century, the gradually emerging trend of increased internationalisation has induced the papacy to discern (and sometimes even initiate) the need to evenly distribute attention to all continents, whose multifaceted emancipation (among others from Europe) 
was increasingly pronounced. ${ }^{2}$ This behaviour of post-war pontiffs has undoubtedly made the Church's perspective more 'catholic' - all-embracing and signified a gradual departure from treating this European institution as an irreplaceable mentor for other regions of the world. ${ }^{3}$

These changing realities, however, have not decreased papal interest in European affairs, including during the recent momentous pontificates. John Paul II and Benedict XVI often made statements that contained reflections on what Europe is, what it will be and what it should be. ${ }^{4}$ Their official speeches on this subject indicated the need to outline the essential features constituting the Old Continent in the late 20th and early 21 st centuries. Both popes agreed that the leading element defining Europe was primarily ideological and spiritual in character. They selected this element as primary among all factors shaping the mentality, governance, production processes and international relations of this part of the world. This approach was guided by the conviction that Christian humanistic values developed in past eras constitute the basic and indispensable core of this continent. Both pontiffs noticed that this axiological and intellectual feature of the Old Continent is currently increasingly challenged by various (secular, utilitarian, religious) cultural and moral trends and ideological systems. They perceived it as a worrying symptom of the weakening of European identity, all the more so because the promotion of these often catchy ideological slogans was accompanied by social antagonisms or even forceful methods of dispute resolution. Moreover, they were aware that these social difficulties could not be addressed by formal and legal instruments used at various structural levels of the European community and in individual countries, because these tools do not guarantee the peaceful stability, unity and development of this continent. According to their predictions (especially Benedict XVI's), the modern world, in particular Europe, is regrettably suffering from extreme materialism, ethical relativism and religious fanaticism, and therefore cannot effectively combat the abovementioned problems. They attributed the main reason for this state of affairs to the lack of a common, mature spiritual and conceptual plane, which indeed set the tone for interpersonal relations and influenced international integration in the past. When the continent was still divided into the Western and Eastern blocs, John Paul II prophetically predicted that the borders of a sovereign and united Europe were determined not so much by geographical location, but by history. He emphasised that, despite historical tragedies and the experience of (even radical) ideologies, our continent could draw on the strength of unity from Christian universalism and cultural diversity, as it had done so at its dawn. In his opinion, it is primarily a 'community of spirit' built on these ideas that is able to guarantee peace and solidarity for Europe. ${ }^{5}$ The teaching of Benedict XVI followed the same approach to Europe as that of the Polish pope. Like his predecessor, he claimed that the geographical boundaries of the Old Continent have secondary and rather emblematic significance. As a result of the historical process, symbolic boundaries, often dependent on numerous internal political or cultural schisms, have been drawn in Europe alongside 
the actual ones. Nevertheless, Benedict XVI undeniably recognised that the essence of European identification goes back to the Roman Empire. Europe's historical and cultural determinants, renewed and enriched by Christianity in subsequent eras, provided a solid foundation for the civilisational, economic and political association of European peoples and states. It was Christianity that became an essential element of European self-identification, as expressed by the term christianitas denoting the western part of the continent. ${ }^{6}$

\section{Critical assessment of modern Europe}

While the position of the aforementioned bishops of Rome in the context of deliberations on the Old Continent can be considered as historically anchored in the European tradition, founded on the combination of Hellenic, Roman and Judeo-Christian thought, it is also worth looking at the insights of the current (since 13 March 2013) successor of Peter. For the first time in the history of the papacy, the head of the Roman Catholic Church is a Jesuit whose spiritual and intellectual formation, as well as his long service in the structures of the Church, were shaped outside of Europe - in Argentina. Unlike his predecessors, who came from the cultural circle of the Mediterranean Basin or Central and Eastern Europe, he is not burdened with the historical conditioning of Europeans. Despite his Italian roots, until his election as pope, he had had no opportunity to or interest in considering European problems due to the legitimate circumstance of being a priest and hierarch of the Church in Argentina. His thoughts on the subject were therefore unknown. However, due to his background, the pope's insights and comments about Europe can be inspiring, because they are formulated from the perspective of an external observer. They may therefore favour an objective and more critical diagnosis of the Old Continent, especially in terms of the prevailing ideological climate, the mental state of societies or institutional efficiency.

When he took office, Francis had to confront both the old challenges and new threats faced by Europe. Religious and social issues resulting from progressing secularism are definitely among the former. A more recent threat, one that reveals the complex interrelations of politics and economy in the wake of the financial crisis and the ensuing cultural crisis, is the threat of Europe's disintegration. As it seems, the old fractures on the continent, which may have been considered a thing of the past, have again become important factors in the destruction of European unity. ${ }^{7}$ Interestingly, these momentous challenges facing the pontificate of Francis, aptly identified by the Italian historian Aldo Giannuli, are similar to the analysis of the current condition of the Church as expressed by Jorge Bergoglio just before his election. His statements as the Primate of Argentina (repeated during his pontificate) about the Church as institution were synthetically summarised in the address at the General Congregation preceding the conclave of March 2013. Bergoglio expressed the opinion that the Church faced a serious challenge of 'coming out from itself'. By this he understood the need to depart from the attitude of 
the Church reduced to 'living in itself, of itself, for itself' in order to be more open to the 'peripheries, not only geographical, but existential'. Therefore, Jorge Bergoglio expected the Church to extend its attention to intellectual, emotional and economic problems affecting the marginalised inhabitants of the world's peripheries. This instruction was intended to commit the Church to abandoning its habit of being locked in a peculiar 'spiritual worldliness' and be more open to people in a non-institutional sense. ${ }^{8}$ Developing this thread in the exhortation of Evangelii Gaudium, he explained that the Church must not hide behind the appearance of piety or love, because it consists in seeking human glory and personal well-being instead of the Lord's glory. ${ }^{9}$ This warning was also intended to remind the Church of the need to follow one of its primary principles, Ecclesia semper reformanda, according to which the institution ought to adapt to the expectations of the era without changing its dogma. ${ }^{10}$ In the words of the then Primate of Argentina, this necessary renewal will allow the evangelical Church to become 'the fruitful mother who lives from 'the sweet and comforting joy of evangelising'. ${ }^{11}$ The identification of the Church with the mother figure, highlighted in the address above and typical of Catholic theology, especially in the 20th century, emphasises that, apart from the metaphysical dimension, it also has a fundamental human aspect. It seems that the use of such a simile endows the Church with causative abilities to survive and develop, which are important from the perspective of human (especially female) nature, because they trigger the instinct for caring for everyone, without exception.

This meaningful pastoral message of J. Bergoglio, identifying significant problems faced by the seemingly 'lost' Church and calling for its renewal, was also applied to the institutions and inhabitants of Europe. During the relatively short period of his service as pope, Francis has shown that he is keenly interested in the current historical moment of the Old Continent, recognising the threats as well as present and future challenges facing this part of the globe. Francis's position in this respect was revealed primarily in his speeches to the European Parliament. Accepting official invitations issued by this important institution of the European Union, he used the opportunity to revisit the ideological assumptions that guided the founding fathers of a united Europe after the tragic experience of war. ${ }^{12}$ At the same time, he noticed that the passage of time, marked by cultural, ideological, geopolitical, economic and technological changes, had also revealed the existence of disturbing tendencies in this community, which may lead to the revision and even negation of these noble, once universal values on which the peaceful and solid coexistence of West European countries was founded. In the much-quoted speech of 25 November 2014, during his first visit to the European Parliament, he even said that Europe on the whole gives an impression of ineptness in solving numerous cultural, ideological and existential difficulties. What is more, in the face of dynamic civilisational challenges, Europe shows procedural failures that neither individual countries nor supranational organisations are able to overcome. These phenomena were not stopped by the process of expanding 
the borders of the European Union, which was intended to strengthen the position and scope of influence of this continent. Similarly, the advancement of globalisation has not only undermined historically well-established Eurocentrism, but has become another factor causing the withdrawal of this important region from the position of a world protagonist. In light of the above, it is not surprising for the pope that the coincidence of these conditions leads to a suspicious and distrustful approach to Europe by external actors. What is more disturbing is that Europe is losing its great ideals that once stimulated its enthusiasm for creativity, drove integration, mobilised societies to seek alternative solutions in various spheres of being, and attracted other continents due to their dynamism. Today's Europe seems to be tired and in decline. Satisfied with the achieved status quo, it does not see the need to search for new solutions to the current difficulties. In Francis's opinion, this continent appears to give 'a general impression of weariness and aging', like 'a grandmother who is no longer fertile and vibrant'. ${ }^{13}$ Although this rather colloquial-sounding statement, typical of this pontificate, did evoke lively comments, it resulted in neither serious political debate nor deepened intellectual inquiry. Undoubtedly, by sharing this reflection, the current successor of Peter felt obliged to mobilise Europe to face what he perceives as severe civilisational challenges for the continent. Overcoming them in this important part of the world should become a priority in order to restore the proper internal vitality and unity, and the proper international position of the cradle of Western civilisation.

Much like his predecessors, Francis perceives the essence of Europe's unsatisfactory performance also in structural terms, primarily in the deficiency or superficiality of the ideological and spiritual plane. A particularly severe drawback in this respect is the widespread promotion of incorrectly understood anthropology. He clearly emphasises that the contemporary approach to the individual and his rights lead to the absolutisation of man and deprives him of the actual biological, cultural and social determinants. Adopting this approach unfortunately results in the affirmation of the subjective rights of individuals accompanied by indifference to the rights of other individuals and relinquishing obligations to them. This is conducive to a lifestyle based on the promotion of egoistic and wasteful consumerism, which is commonly accompanied by the so-called culture of rejection. This attitude clearly influences the breakdown of social bonds (family, professional, local, national, supranational), the arbitrary exclusion of certain categories of people (homeless, lonely, elderly, helpless, immigrants and refugees) from public life, and finally leads to denying the most vulnerable beings (unborn children, the bedridden) the right to exist. According to the Pope, this peculiar egocentrism, coupled with a lack of social sensitivity, is a manifestation of ideological emptiness (which characterises the 'Western' world) that is becoming one of the most important civilisational problems faced by modern Europe. ${ }^{14}$ It is all the more worrying for him because this shallow and uncertain ground favours extremist attitudes. Moreover, it is increasingly conducive to violence, hatred and social 
conflicts rooted in cultural, moral, ideological, religious or ethnic issues. The pope notices another significant imperfection of this continent in the systemic organisation and functioning of Europe's governing institutions at the national and supranational level. The excessive bureaucracy and structural formalism that characterise them translate into practical difficulties in ensuring public security and meeting the existential needs of societies; they also paralyse praiseworthy bottom-up initiatives. Francis is convinced that the promotion of the aforementioned superficial culture of life in combination with excessive functionalism of administrative structures destroy Europe's mental and material achievements. These factors lead to the loss of momentum in reunification efforts and allow the technocratic paradigm to rule. ${ }^{15}$ This pessimistic evaluation of modern Europe, similar to the diagnosis of the Church, expressed the pope's concerns about their future. By using the rather original comparison to the poor condition of the 'spirit and body' of an older woman, Francis clearly wanted to stress Europe's structural weakness, intellectual crisis and loss of vitality. As in the case of the Church, his suggestive reference to feminine nature was intended to emphasise the uniqueness of the female sex, but first and foremost to highlight women's indisputably crucial role in the gift of life, continuity of existence and possibility of development, as well as their ability to care for and protect everyone in need. ${ }^{16}$ In the context of Francis's teaching, this symbolic reference to the woman - mother and grandmother, with her instinctive, emotional and cultural predispositions indicating the primacy of man's relational attitude - functions as a reminder about the foundations of civilisation, also in Europe. He is convinced that rejecting this heritage in the long run will not be conducive to the expected dignified existence or harmonious development of both human society and spiritual community as well as political organisation.

\section{Prospects for the renewal of the European community}

Thus, by drawing a positive picture of the future of Europe, the pope encourages the restoration of the noble ideals of the founding fathers of the European Union. Respectful to the boldly conceived idea of the unification project, he stresses that it was underlain by the need to build a community fundamentally based on the Christian concept of the person. The essence of this idea was the recognition of 'transcendent dignity' in man as the foundation for the unity of Europeans and the functioning of their political and legal structures. As was the case with the initiators of the unification of Europe, Francis selected this aspect as the main thread in his reflection on the real potential of Europe and the need to return to what its spiritual unity is based upon. His reference to human dignity derived from God was also meant to emphasise the moral aspect of human nature. These determinants justify the essence of inherent and inalienable rights, which are vested in every human being without exception. As the pope emphasised, these individual attributes of man simultaneously confirm his relational nature and the ability to create a 
real social community. It is the ethical and social features inscribed in human nature that allow individuals to responsibly make free and wise choices for the benefit of solidarity and interdependent human relations. Francis reminded his audience that this aspect of Christian heritage, which accounts for both key dimensions of human nature (transcendent dignity and relativity), undeniably contributed to the formation of European humanism and the development of civilisation. ${ }^{17}$ This unique spiritual unity is identified by the pope with an intellectual formation that causes some people to belong to each other, "that each of our lives is anchored in the lives of others', ${ }^{18}$ that we are not lone nomads and that human life makes sense first and foremost within a spiritual community. Moreover, he emphasised that the essence of true spirituality lies in God as all-powerful and Creator. If we deprive it of this source, we will end up worshipping other earthly powers (gods of power, money, possession) or usurp the place of God. ${ }^{19}$ Therefore, by emphasising the indisputable importance of this achievement of European civilisation, the pope shows his conviction that it should continue to function as an absolute signpost for the benefit of future generations. He believes that openness to the Christian concept of anthropology will provide Europe in the future with a harmonious combination of the now weakened spiritual element with institutional pragmatism. The correlation of these two planes will determine whether Europe will be teeming with life and developing, or whether it will become increasingly stagnant and forgotten. He simultaneously emphasises that the modern, secular (of Enlightenment origin) Europe will not lose its identity if it returns to a form of humanism which is rooted in Christianity. On the contrary, it can be enriched with values that will help it overcome the numerous social tensions or the aggressive, externalist attitudes of certain environments. Contrary to the proclamations of certain opinion-forming circles or secular institutions, he asserts that the return to the Christian element of humanism should not raise unjustified fears about the Church's inclinations to impose religious integrity or eliminate ideological freedom. It should be remembered that modern European and national institutions in practice refer to shared (often Christian) ideals, such as the principle of the common good, subsidiarity, solidarity, justice, peace and a humanism centred on respect for the dignity of the human person. ${ }^{20}$

Just as the secular world expects heterogeneity from the Church, the pope also expects the world to interpret the motto of the European Union - 'unity in diversity' - in the spirit of the abovementioned common values. ${ }^{21}$ In this context, he warned European institutions not to succumb to the harmful centralistic manner of harmonising the various (intellectual, cultural, political or economic) levels of life of Europeans. Such uniformity destroys the blessing of diversity, favouring the promotion of a new incarnation of political nominalism, which is incompatible with the spirit of democracy. It also serves the universal dictate of relativism, 'anti-historic fundamentalisms' and an ethics devoid of life's wisdom. It shows dangerous tendencies to reduce the wealth of private and public life views to the sphere of ideas, 'words, images, 


\section{Ewa Kozerska}

sophistry'. In this way, European institutions impose a form of governance that is imaginary and detached from real and often complex problems, giving the impression of a flattened, one-dimensional reality. As a consequence, the pope noted, the cognitive condition of societies is impoverished and it is exposed to the 'ideological colonisation' visible in Europe. ${ }^{22}$ From the perspective of space and time, such colonisation generates deepened ideological divisions, which often take the form of terrorism. Thus, Francis clearly warns against succumbing to the pressure of the incomprehensible tension between ideas and realities, which he understands as the dissonance between the spiritual and intellectual sphere in Europe, which is already devoid of content or even in atrophy, and the excessive adherence to uniformity tinged with functionalism and pragmatism. In his opinion, for the good of Europe, there must be a dialogue between these categories that would allow 'the idea to capture, understand and direct reality'. ${ }^{23}$ To explain this non-innovative discourse on the correlation between thought and reality, which already troubled ancient philosophers, the pope used the readily recognisable painting The School of Athens. It was not the first time in his pontificate that he had referred to this fresco by Rafael Santi. The way he sees it, the painting symbolically presents the relation between the idea, associated by the pope with the supernatural world, and the concrete world, which reflects the crux of European history. The content of this artistic work, he emphasised, should remind the contemporaries of the truth that the idea (heaven) is to illustrate openness to the transcendent God, which is not foreign to Europeans, and temporality (earth) - a practical ability to manage various complex existential situations. ${ }^{24}$ In the pope's opinion, this truth cannot be manipulated. Misinterpretations of this emblematic message, for which both secular and religious leaders are responsible, have spread the impression that these categories of thought are polar opposites. This cognitive misunderstanding has not only resulted in a disastrous separation of the spiritual and ideological sphere from politics, but also led to an incorrect reduction of these concepts to lapidary rhetoric or unreal intellectualism. In his opinion, this disturbing focus on the plane of pure ideas, detached from reality, as Plato did, is dangerous. It threatens to establish a susceptibility to harmful Gnostic views in European institutions, such as the Church, ones which focus only on the subjective logic of thinking and one's own experiences. ${ }^{25}$ As the pope emphasised, such a faulty isolated pseudoscientific mentality ought to be questioned. This attitude will prevent the building of a future that is deeply rooted in a true humanistic heritage and prevent the verification of the defects of the present time. He argues that opening to the Christian tradition of humanism will contribute to overcoming this incomprehensible tension between thought and fact and will creatively affect the indispensable relationship between religion and society (and politics). He is convinced that just as reason and faith, so too religion and people (and their institutions) are able to properly enlighten and support each other. In a situation where both sides succumb to fanatical extremes, it will help to 'cleanse' them of ideological extremisms that only generate destructive 
aggression and violence. ${ }^{26}$ The future of Europe, like its glorious past, is therefore dependent on the rediscovery of the inseparable link between the idea (with Christian spiritual and intellectual roots) and reality (a multidimensional real existence).

In Francis's opinion, putting these relations in order will allow modern Europe to return to the correct formula of the unity of the community the family of European nations. He rightly noted that it is expressed in the freedom of each member state to cultivate its own local identity and support grassroots, creative citizenship. The motto of the EU should not be an empty phrase, but actually oblige the European community to adopt the attitude of a protagonist of the values of individual national historical traditions. At the same time, this creed should contain any tendencies to succumb to unjustifiable prejudices or cultural phobias and intellectual manipulations. In the belief of the Bishop of Rome, it is the ability to combine the idea of unity with various regional particularisms that can promote the authenticity desired by the European community and by individual democratic states, favouring political pluralism. ${ }^{27}$ That is why Europe must confront its problems by means of the so-called polarity and transversality. He noted that the history of modern Europe can no longer be geopolitically reduced to a bi- or tri-polar structure in which decision-making in common matters is reserved for a narrow and intrinsic elite. This concept is currently undergoing a global experiment in multipolarity that is both connective and disintegratory in terms of culture (not necessarily overlapping with specific state borders), ethnicity, language, politics or religion. This challenge is connected with the search for constructive harmony, but also with the danger of delusionary yielding to a pragmatic hegemony that destroys authentic cultures and religions of nations. Building the multipolarity of European internal relations and tensions requires the recognition and preservation of the unique features of each nation. The consolidation of the continent also requires transversality, which the pope understands as intergenerational dialogue, and even a cross-sectional exchange of opinions. This is dependent on empathy between generations, embracing the historical method of development by exchanging thoughts with representatives of other religious, political, or cultural identities. Francis is convinced that the aforementioned spirit of openness, characteristic of youthful mentality, will allow Europe to make progress towards a peace that is fraternal and free, acquire skills to bridge divisions and build mutual respect on genuine tolerance. ${ }^{28}$

This typically European 'unity in diversity' was also considered by the pope from the perspective of tensions between the whole - the European community - and its parts - the individual nations. On the one hand, that which is local, original, rooted in and committed to the history of one's own place, favours personal and state development, which is an added value. However, the adoption of this attitude by individuals, social groups or countries may also create the danger of building a 'folkloristic museum of local hermits', isolated and deprived of the ability to respond to differences, which may 
lead to the sterility of such a community. On the other hand, in the spirit of the Aristotelians, the pope remarked that the whole is greater than the sum of its parts and that one should not tightly cling only to local and minor matters. One must first and foremost keep in mind the greater good that benefits everyone, not just a few. However, such a broader European perspective should not condemn nations and individuals to global universalism, in which citizens adopt a conformist attitude and are subject to uprooting. The pope acknowledged that the European community should harmoniously cooperate with individual countries so that neither side falls into these extreme behaviours. This ability to interact should therefore consist of combining the positive aspects of the unique identities of smaller communities or states with their commitment to the benefit of a larger (whole) community, from which they receive in return new stimuli for development. ${ }^{29}$ The real unity and integrity of peoples lies in the fact that they maintain their identity in a universal order. What is more, these values are co-created by the general public seeking true common good which does not exclude anyone from creating and using bonum commune. In this context, Francis warned against public use (especially by politicians or the media) of intellectual confusion to justify new forms of discrimination, authoritarian tendencies or short-sighted aggressive behaviour of ethnic groups or religious fundamentalists, which can only generate violence ${ }^{30}$ Religious, political and ethnic pluralism means respect even for different values and their adherents, which excludes the privatisation of ideas, religion, culture or politics with the intention of muting them or confining them to their own institutional limits. According to the pope, it is also important to return to a good tradition (identified with a new form of 'agora'), enabling the free exchange of opinions by secular and religious institutions that mutually respect each other's autonomy. In his opinion, a reference to pluralistic discourse will enable a broader view in search of the true common good. He warned that imposing a unified cultural, religious or political concept while eliminating the richness of these traditions eliminates tolerance and peace in the long run. It deepens resentment and contributes to the breakup of the common plane of existence. ${ }^{31}$

The renewal of the European community formula as proposed by Francis requires the affirmation of every human rooted in Christian humanism in the currently favourable conditions of lawful democracy. He advises the European community to pay special attention to fundamental human rights, which are treated as the undisputed foundation of states, supranational organisations, and the civilisational heritage of this continent. Among them, he singles out the rights of the basic social cell - the family. Due its procreative skills, this natural community ensures generational continuity, but also teaches social bonds and builds a home that consolidates the past with future generations. The family also plays an important role in the intellectual, technical (including ecological) and spiritual formation of man. It undeniably influences the individual discovery of one's own potential, promotes the relational attitude towards other people and shapes a holistic, integrated development. ${ }^{32}$ The 
pope's conscious emphasis on the stature of the family and its rights as elementary guidelines for national and European policies should be, in line with his postulates, supported by an appropriate employment strategy based on the dignity of the ethos of work. This aspect of public policy guarantees material security for families and creates an innovative and responsible social attitude. In the pope's opinion, in the context of family rights and the right to employment, one must not forget about the human capital of immigrants, whose presence on the European continent can in many ways enrich its weakened potential and alleviate labour shortages. These challenges, in his conviction, require the European community to provide adequate support for the cultural identity of individual nations, clear legislation protecting the rights of citizens - but also of immigrants, who in the current circumstances constitute an important part of the Old Continent's community. ${ }^{33}$ Importantly, the pope emphasises that modern Europe is primarily responsible for implementing its own rudimentary objectives and overcoming the difficulties associated with them. At the same time, in accordance with his message about openness to the world's periphery, he recommends that Europe should feel ready to help non-European countries, especially those whose difficult economic and political situation causes mass emigration of their citizens to the Old Continent. Europe should be a pioneer in addressing these important causes of migration and in promoting a role model of creating civic dignity. Similarly, it should be open to dialogue with countries applying for admission to the EU and to cooperation with those that want to remain outside its sphere of influence. Its particular duty in this respect is cooperation or support in resolving conflicts, some of which are also experienced by EU countries (including religious fundamentalism), or combating international terrorism. This is a primary challenge, especially because these infamous events are fuelled by the arms race, arms trade and human trafficking, all of which stem from contempt for or instrumental treatment of human life. ${ }^{34}$

The problems caused by an inefficient migration policy and numerous violent conflicts mainly due to ideological (including religious), ethnic and economic reasons, constitutes one of the most acute symptoms of the weaknesses of modern Europe that trouble the current pontiff. In Francis's opinion, these negative phenomena are fuelled by the desire to dominate others or to possess worldly goods and constitute another example of how Christian humanism is misunderstood. The pope reminds in this context that the rejection of the so-called culture of conflict, embroiled in intimidation or marginalisation of people with different views or lifestyles, requires long-term, continuous education in a spirit of peace and communal cooperation. Each conflict must be faced, because ignoring it causes internal emaciation, distrust and fear, slipping into fruitless contradictions and horizontal inwardness that typically erode interpersonal relations, deepen tensions and unfortunately claim innocent victims. ${ }^{35}$ In Francis's opinion, the pursuit of peace should not be understood only in terms of avoiding conflicts and wars, or as temporary truces imposed by utilitarian agreements. True peace is characterised by free and 
fraternal spiritual reconciliation. The future of Europe needs a memory of the past based on true humanitarianism, not on mechanical, formalised and uniform policies of states and European institutions. ${ }^{36} \mathrm{He}$ therefore instructed Europe (or rather its decision-makers) not to evade the obligation to constantly reflect on whether its humanistic, artistic, technical, social, political, economic and religious heritage is only a relic of the past and whether the current appearance of permanence can still be an inspiration for mankind. In his view, the leading role in the implementation of this task falls to the Council of Europe and the European Court of Human Rights (the guardian of respect for human rights), which should always bear in mind the historical heritage of the continent on which the founding fathers built its post-war history. This is a prerequisite if Europe wants to be a multilateral leader and reference point for the rest of the world. Its leaders must remember that creativity and the ability to go beyond one's own limits lie in the nature of this continent. It was proven by overcoming the tragic effects of wars experienced by Europe in the 20th century. Resignation and fatigue (as in the symbolically evocative figure of the 'grandmother') are therefore not an inherent feature of this part of the globe, and all obstacles should be treated as catalysts for unity. ${ }^{37}$

\section{Conclusion}

In summary, it ought to be emphasised that Francis, like his two great predecessors on the Chair of Peter, is able to accurately diagnose the weaknesses of the Old Continent. At the same time, his positive advice to Europe's residents and institutions, which is intended to promote the solidarity, peace and unity of the continent, in principle does not diverge from the key postulates of John Paul II and Benedict XVI. Of course, the social and structural threats in modern Europe are different (increased migration, 'ideological colonization', dictate of formalism and institutional centralism), or reveal the intensification of previously existing problems (economic disparities, a 'culture of exclusion', religious fanaticism, secularism, dechristianisation, terrorism). This has resulted in enriching Francis's teaching in comparison with the previous pontiffs by adding new, consequential and accurate reflections. It is also worth noting that in their predictions and instructions, all popes used a language that was characteristic of their pontificates, which probably makes their teaching seem more differentiated. What they undoubtedly share is the message that Europe cannot abandon its cultural and ideological heritage, on which it was founded and which is the direction for its future. In the case of Francis's teaching, the need for Europe and the Church to undergo mental renewal and institutional reform in line with the original spirit of the Gospel is clearly exposed. The pope's recommendations about the necessity of spiritual and institutional transformation are formulated due to his fear of the possibility of the collapse of Europe, which is often weak, inefficient and deprived of vitality. In his view, this disturbing sign of the times in the 
form of both religious and secular order plunging into 'spiritual worldliness' requires a revival of the Christian aspect of humanism. For Francis, it simply means a 'continuous process of humanization', undisputedly founded on a transcendent and relational human nature, whose dignity and rights ought to be guarded by law-abiding democratic states and supranational organisations. The pope is convinced that this fundamental premise enables the recreation of a truly universal spiritual community, which is the sine qua non of the cultural and ideological foundation of a united Europe. At the same time, it guarantees solid international relations based on solidarity. What is more, he predicts that it will result in structures which, instead of following purely technical and dehumanised rules, respect solutions based on the multicultural identity of nations and grassroots activity of all generations, truly serving the process of the integration of the continent.

\section{Notes}

1 Grzegorz Polak, Franciszek. Papież wielkiej nadziei, (Znak 2013), 138.

2 See more in enunciations of John XXIII (Mater et Magistra, Pacem in terris) and Paul VI (Populorum Progressio, Octogesima Adveniens); cf Marian Banaszak, 'Historia Kościoła Katolickiego. Czasy najnowsze 1914-1978', (1992), 4, Akademia Teologii Katolickiej, 337-361; Zygmunt Zieliński, Papieże i papiestwo dwóch ostatnich wieków, (3rd edition, Pax 1999), 413-429, 438-490.

3 Polak, (n 1), 127, 138.

4 In the opinion of the Italian historian Aldo Giannuli, the universalist course of John Paul II was somewhat abandoned by his successor in favour of Eurocentrism. In the opinion of the researcher, unlike Benedict XVI, who focused mainly on the crusade against the threat of relativism to Western civilisation, Francis would rather continue the openness of the Polish pope to understanding and establishing dialogue with the whole world. Aldo Giannuli, Papa Francesco fra religione e politica. Chi è, quale Chiesa si trova a governare, quali sfide globali dovrà affrontare, (Adriano Salani Editore S.p.A. 2013), 68, 74; Tomasz Terlikowski, Operacja Franciszek. Sześć medialnych mitów na temat papieża, (Fronda 2014), 34.

5 John Paul II, 'Discorso di Giovanni Paolo II durante la visita al Parlamento Europeo, 11 October 1988', (1988) ed Polish L'Osservatore Romano, (11), 11 and John Paul II, 'Homily at the Cathedral of Gniezno on the 1000 year anniversary of the death of St Adalbert, 3 June 1997' in Leszek Sosnowski and Gabriel Turowski (choice and elabor.), Europa zjednoczona w Chrystusie: Antologia, (Biały Kruk 2011), 306.

6 Joseph Ratzinger, Europe: Today and Tomorrow, (San Paolo 2004), translated into Polish by Stanisław Czerwik (Jedność 2005), 9-11, and more broadly: Tomasz Schramm, Tożsamość Europy a chrześcijaństwo, (Księgarnia Św. Wojciecha 2005).

7 Giannuli, (n 4), 75; cf Heribert F Koeck, 'Szczęście w nieszczęściu. Jak dużego kryzysu potrzeba, aby zreformować Unię Europejską?' in Eugeniusz Piontek, Katarzyna Karasiewicz (eds), Quo vadis Europo III?, (Urząd Komitetu Integracji Europejskiej 2009), 29, 34.

8 The outline of the programme of reforms and renewal of the Church presented by Jorge Bergoglio, and later Francis, clearly refers to the guiding ideals of the 
mendicant orders, initiated by the Franciscan and Dominican communities in the so-called New Middle Ages. Their main goal was to preach the Gospel in the spirit of the first disciples. Marian Banaszak, 'Historia Kościoła Katolickiego. Średniowiecze', (1989), 2, Akademia Teologii Katolickiej, 183-189. It should also be noted that this direction of the renewal of the Church appeared in the concept of accomodata renovatio, initiated by Leo XIII and strongly emphasised during the pontificates of John XXIII and Paul VI, although it was not directly referred to by Francis. Cf Rerum Novarum. Encyclical of Pope Leo XIII on Capital and Labour in Nauczanie społeczne Kościoła, (Ośrodek Dokumentacji i Studiów Społecznych 1984), 12-35.

9 There is more on Francis's understanding of 'spiritual wordliness' in Evangelii Gaudium (Święty Paweł 2014), pt. 93-97; Andrea Tornielli, Jorge Mario Bergoglio: Francis: Pope of a New World, (Piemme 2013), translated into Polish by Krystyna Kozak and Krzysztof Stopa (Jedność 2013), 128, 131-132.

10 Giannuli, (n 4), 97.

11 Austen Ivereigh, The Great Reformer: Francis and the Making of a Radical Pope, (Allen \& Unwin 2015), translated into Polish by Marcin Masny (Niecałe 2015), 417.

12 Not all founding fathers were guided by Christian values founded on transcendent dignity, to which Francis refers. For more, see footnote 7 in Ewa Kozerska, Papiez Franciszek o prawie (2016) XV, Miscellanea Historico-Iuridica, 2, 343, 346.

13 Francis, 'Between Dignity and Transcendence: Address of Pope Francis to the European Parliament, 25 November 2014', (2014) ed Polish L'Osservatore Romano, 12, 9-10; cf also Francis, 'What Happened to You, Europe? Address of His Holiness Pope Francis - Conferral of the Charlemagne Prize, 6 May 2016', (2016) ed Polish L'Osservatore Romano, 5, 30.

$14 \mathrm{Cf}$ Francis, Laudato Si, pt. 46, 109, 117 www.vatican.va/content/francesco/ en/encyclicals/documents/papa-francesco_20150524_enciclica-laudato-si.html accessed on 10 July 2020; Bergoglio, 'Homily of 25 March 2012' translated into Polish by Xavier Bordas i Hanna Prószyńska-Bordas in Chciałbym Kościoła ubogiego dla ubogich, (M 2013), 66; Aldo M Valli, Le sorprese di Dio. I giorni della rivoluzione di Francesco, (Ancora 2013), translated into Polish by Krystyna Kozak (Jedność 2015), 34-37.

15 Cf Francis, Laudato Si, pt. 111, 118; Walter Kasper, Witness of Mercy, (Mauri Spagnol 2015), translated into Polish by Michał Szwemin (ARTI 2016), 26-27.

16 Francis, 'Between Dignity and Transcendence: Address of Pope Francis to the European Parliament, 25 November 2014', (n 13), 9-13; cf also Francis, 'What Happened to You, Europe? Address of His Holiness Pope Francis - Conferral of the Charlemagne Prize, 6 May 2016', (n 13), 34; and Valli, (n 14), 31-32.

17 In the context of the inherent features of human nature, Francis refers to the formula of 'human ecology' used by his predecessor Benedict XVI ('The Listening Heart. Reflections on the Foundations of Law: Speech at the Bundestag on 22 September 2011', (2011) ed Polish 'L'Osservatore Romano, 10-11, 38, 41). It is worth noting, however, that in Francis's teaching the issue of human relativity, as he terms it, is much more highlighted than in the previous pontificate due to the currently more significant breakup of bonds and social unity. Francis, 'Between Dignity and Transcendence: Address of Pope Francis to the European Parliament, 25 November 2014', (n 13), 9-11; and Francis, Laudato Si, pt. 43, 81, 119, 216; cf Bergoglio, 'Seminar of 30 September 2009: The Social Debts of Our 
Time', translated into Polish by Krzysztof Gołębiowski, in 'Chciałbym Kościoła ubogiego dla ubogich',(n 14), 34-35.

18 Francis, 'Do Not Forget About Your Roots: Apostolic Journey of His Holiness Pope Francis to Romania, 1 June 2019', (2019), 7-8, ed Polish L'Osservatore Romano, 27, 28; cf. Andrea Tornielli, 'A Road Map for the Future of Europe and its Inhabitants', (2019), 7-8, ed Polish L'Osservatore Romano, 16, 17.

19 Francis, Laudato $\mathrm{Si}$, pt. 75.

20 Francis, 'Between Dignity and Transcendence: Address of Pope Francis to the European Parliament, 25 November 2014', (n 13), 11.

21 This motto was announced at the session of the European Parliament on 4 May 2000. More: Dorota Jurkiewicz-Ekhert, 'Od Traktatu o Unii Europejskiej do Europejskiej Agendy dla Kultury - narodziny i rozwój polityki kulturalnej UE', (2015), 1, Studia Europejskie, 65, 65-67.

22 Francis, 'Between Dignity and Transcendence: Address of Pope Francis to the European Parliament, 25 November 2014', (n 13), 11-12; Francis, 'What Happened to You, Europe? Address of His Holiness Pope Francis - Conferral of the Charlemagne Prize, 6 May 2016', (n 13), 31. Cf. Jorge Bergoglio and Abraham Skorka, On Heaven and Earth. Pope Francis on Faith, Family and the Church in the Twenty-First Century, (Random House Mondadori S.A. 2010), translated into Polish Marta Szafrańska-Brandt, (Znak 2013), 85-88.

23 Francis, Evangelii Gaudium, pt. 231-233; and Bergoglio, True Power Is Service, (Editorial Claretiana 2013), translated into Polish by Agnieszka FijałkowskaŻydok (Esprit 2013), 73, 324-326.

24 Francis, 'Between Dignity and Transcendence: Address of Pope Francis to the European Parliament, 25 November 2014', (n 13), 11. The pope metaphorically illustrated the condition of modern Europe also by referring to poems by the Italian poet Clemente Rebora ('Il pioppo' in Canti dell'Infermita, Vanni Scheiwiller 1957), whose spiritual transformation caused his accession to Catholicism, in Francis, 'Memory, Courage, Utopia: Address of Pope Francis to the Council of Europe, 25 November 2014', (2014) ed Polish L'Osservatore Romano, 12, 14, 15.

25 Cf Francis, Evangelii Gaudium, pt. 94. Cf also Bergoglio and Skorka, (n 22), 151-158.

26 Francis, 'Between Dignity and Transcendence: Address of Pope Francis to the European Parliament, 25 November 2014', (n 13), 11; Francis, 'Memory, Courage, Utopia: Address of Pope Francis to the Council of Europe, 25 November 2014', (n 24), 17.

27 Francis, 'Between Dignity and Transcendence: Address of Pope Francis to the European Parliament, 25 November 2014', (n 13), 12.

28 Francis, 'Memory, Courage, Utopia: Address of Pope Francis to the Council of Europe, 25 November 2014', (n 24), 16-17; cf Jorge Bergoglio, Exactingness and Passion: Challenges for Christian Educators, (Editorial Claretiana 2013), translated into Polish by Lidia Wrona (Esprit 2013), 113.

29 Francis, Evangelii Gaudium, pt. 234-236; cf Bergoglio, Exactingness and Passion: Challenges for Christian Educators, (n 28), 107-108; cf Kasper, (n 15), $35,37$.

30 Francis, Evangelii Gaudium, pt. 255-256; Francis, 'Dialogue and Cooperation against Fundamentalism: Apostolic Journey of His Holiness Pope Francis to Morocco, 30 March 2019', (2019) ed Polish L'Osservatore Romano, (4-5), 20, 20-23. 
31 Francis, Evangelii Gaudium, pt. 255; Francis, 'Memory, Courage, Utopia: Address of Pope Francis to the Council of Europe, 25 November 2014', (n 24), 18.

32 Francis, 'Between Dignity and Transcendence: Address of Pope Francis to the European Parliament, 25 November 2014', (n 13), 12; cf Francis, 'Dialogue and Cooperation against Fundamentalism: Apostolic Journey of His Holiness Pope Francis to Morocco, 30 March 2019', (n 18), 28; cf Bergoglio, Open Mind, Faithful Heart, (Editorial Claretiana 2013), translated into Polish by Małgorzata Łuszczak and Małgorzata Grygierowska (Esprit 2013), 122.

33 Francis, 'Between Dignity and Transcendence: Address of Pope Francis to the European Parliament, 25 November 2014', (n 13), 13; cf Francis, 'Dialogue and Cooperation against Fundamentalism: Apostolic Journey of His Holiness Pope Francis to Morocco, 30 March 2019', (n 30), 21. The problem of migration in the teaching of this pope is a constant object of reflection and pastoral care. Francis, 'Message of His Holiness Pope Francis for the 101st World Day of Migrants and Refugees, 3 September 2014', (2014) ed Polish L'Osservatore Romano, 10, 4-5; Francis, 'Message of His Holiness Pope Francis for the World Day of Migrants and Refugees, 15 September 2015', (2015) ed Polish L'Osservatore Romano, $10,10-12$.

34 Francis, 'Memory, Courage, Utopia: Address of Pope Francis to the Council of Europe, 25 November 2014', (n 24), 15.

35 Cf. Francis, 'Message of His Holiness Pope Francis for the Celebration of the 53rd World Day of Peace' 1 January 2020, http://w2.vatican.va/content/francesco/en/ messages/peace/documents/papa-francesco_20191208_messaggio-53giornatam ondiale-pace2020.html accessed on 10 May 2020.

36 Francis, 'Between Dignity and Transcendence: Address of Pope Francis to the European Parliament, 25 November 2014', (n 13), 13; cf Francis, 'Memory, Courage, Utopia: Address of Pope Francis to the Council of Europe, 25 November 2014', (n 24), 14.

37 Francis, 'Memory, Courage, Utopia: Address of Pope Francis to the Council of Europe, 25 November 2014', (n 24), 16; Francis, 'What Happened to You, Europe? Address of His Holiness Pope Francis - Conferral of the Charlemagne Prize, 6 May 2016', (n 13), 31; Kasper, (n 15), 82-83. 